\title{
Erratum to: Organization Performance Evaluation Using System Thinking: A Study in Brazilian Chemical Organizations Models
}

\author{
Luciana Oranges Cezarino • Flavio Hourneaux Junior • \\ Hamilton Luiz Correa
}

Published online: 23 July 2011

(C) Springer Science+Business Media, LLC 2011

\section{Erratum to: Syst Pract Action Res DOI 10.1007/s11213-011-9198-4}

Please note that the following is the current name of the second author of this article:

Flavio Hourneaux Junior

The online version of the original article can be found under doi:10.1007/s11213-011-9198-4.

L. O. Cezarino · F. Hourneaux Junior · H. L. Correa

Business Department, University of Sao Paulo, Sao Paulo, SP, Brazil

L. O. Cezarino $(\bowtie)$

FEA-USP, Guiana Inglesa Street, 450 Apt. 63B, Ribeirão Preto, SP 14075-210, Brazil

e-mail: lcezarino@gmail.com 